\title{
Clarification of Linaclotide Pharmacology Presented in a Recent Clinical Study of Plecanatide
}

\author{
Robert W. Busby $\cdot$ Stephan Ortiz
}

Received: 30 September 2013/Accepted: 12 November 2013/Published online: 21 March 2014

(C) The Author(s) 2014. This article is published with open access at Springerlink.com

\section{Dear Editor:}

We read with great interest the study of plecanatide, a guanylate cyclase C (GC-C) agonist, reported by Shailubhai et al. [1] in the recent issue of Digestive Diseases and Sciences. We have noticed some factually inaccurate statements with respect to the GC-C agonist linaclotide and the comparisons among GC-C agonists. On behalf of the companies that market linaclotide, we felt compelled to write to address these inaccuracies.

In the discussion section, the authors address varying degrees of pH-dependent activity among GC-C agonists. The GC-C binding affinities of guanylin and uroguanylin, and the GC-C activated production of cGMP by these endogenous hormones, have been shown to be affected by $\mathrm{pH}[2-4]$. The authors correctly note that the activity of linaclotide is not $\mathrm{pH}$ dependent and that the binding affinities of linaclotide to GC-C were similar across a broad, physiologically relevant $\mathrm{pH}$ range ( $\mathrm{pH} 5-8)$. This $\mathrm{pH}$-independence results in linaclotide being active at GC$\mathrm{C}$ along the entire longitudinal axis of the intestinal tract [2]. However, the authors' assertion that this $\mathrm{pH}$-independence leads to "uncontrolled activation" of GC-C is not substantiated by the reference cited [2]. In fact, the preclinical study cited demonstrates that linaclotide binds to and activates GC-C in a concentration-dependent manner

R. W. Busby ( $₫)$

Ironwood Pharmaceuticals, Inc., 301 Binney Street, Cambridge,

MA 02142, USA

e-mail: rbusby@ironwoodpharma.com

S. Ortiz

Forest Research Institute, Inc., Harborside Financial Center,

Plaza V, Jersey City, NJ 07311, USA
[2]; in other words, the activity of linaclotide is controlled by virtue of being delivered as a discrete oral dose.

In addition, Shailubhai et al. also put forth a theory that the $\mathrm{pH}$-independence of $E$. coli enterotoxin ST peptide (ST) is the reason for extreme cases of diarrhea that can result from enterotoxigenic E. coli (ETEC) infections. This suggestion is not supported by previous or current research into the causes and treatment of ETEC [5-7]. In an ETEC infection, $E$. coli infects the entire intestinal tract and is continuously replicating and secreting multiple toxins. It is important to remember that persistent exposure to these toxins throughout the course of an ETEC infection is not in any way analogous to the more transient exposure to a therapeutic GC-C agonist following a discrete oral dose [68]. Furthermore, the position of Shailubhai et al. does not take into account the proteolytic degradation that any orally delivered GC-C agonist will undergo [8].

This is an exciting time for the field of GC-C pharmacology. We look forward to contributing to and reading about future research on GC-C agonists and GC-C pharmacology.

\section{Reply}

The communication "Clarification of Linaclotide Pharmacology Presented in a Recent Clinical Study of Plecanatide" by Busby and Ortiz was published in response to our article recently published in Digestive Diseases and Sciences [1]. Busby and Ortiz called into question what they believe to be factually inaccurate statements that they feel "compelled" to address. On behalf of my colleagues, I am equally compelled to respond to apparent misinterpretations of our statements regarding the comparative characteristics of guanylate cyclase-C (GC-C) agonists. 
Busby and Ortiz agree with our statement in the Discussion that, "linaclotide, a homolog of E. coli heat-stable (ST) enterotoxin, activates GC-C receptors in a $\mathrm{pH}$-independent manner" but take umbrage with our including the statement "uncontrolled manner." The high incidence of diarrhea observed in clinical evaluations with linaclotide [9] may possibly be due to uncontrolled activation of GC-C receptors in the GI tract due to the lack of luminal $\mathrm{pH}$ dependence of linaclotide in activation of GC-C receptors, compared with the $\mathrm{pH}$-dependence of GC-C activation by its physiological activator uroguanylin [10]. We hypothesize that this loss of $\mathrm{pH}$-dependence may remove a physiological check on GC-C activation, which, in some cases may be associated with severe diarrhea.

Busby and Ortiz further state that: "In fact, the preclinical study cited [2] demonstrates that linaclotide binds to and activates GC-C in a concentration-dependent manner; in other words, the activity of linaclotide is controlled by virtue of being delivered as a discrete oral dose". Although Busby et al. [2] cite in vitro data to support this supposition, there does not appear to be a significant or consistent relationship between oral dose and physiological response in humans. For example, using occurrence of diarrhea as a surrogate for GC-C activation, doubling the daily oral dose from 145 to $290 \mu \mathrm{g}$, had no discernible impact on the rate of diarrhea (16 vs. $14.2 \%$ ) observed in clinical trials [9]. Similarly, there was no apparent doseefficacy relationship observed for the primary endpoint (weekly frequency of three or more complete spontaneous bowel movements (CSBMs) and an increase of one or more CSBMs from baseline for at least 9 weeks of the 12-week treatment period). The dose-responsiveness of linaclotide therapy in humans is thus not well-supported by current clinical data.

We would also like to disagree with the statement made by Busby and Ortiz: “...Shailubhai et al. also put forth a theory that the $\mathrm{pH}$-independence of $E$. coli heat stable (ST) enterotoxin is the reason for extreme cases of diarrhea that can result from enterotoxigenic E. coli (ETEC) infections." We simply speculated that the cases of severe diarrhea observed in response to linaclotide therapy in clinical trials may be due to the $\mathrm{pH}$-independence of GC-C activation, thus sharing the pathologic activation mechanism with ST enterotoxin without drawing direct parallels to the mechanism of ETEC-associated diarrhea.

This is an exciting time for clinicians, who now or will have available several novel compounds at their disposal for the treatment of constipation. We hope that further basic and clinical study will further increase the understanding of the mechanism of GC-C activators and continue to improve their therapeutic utility and safety.

Kunwar Shailubhai, PhD Synergy Pharmaceuticals, Inc., 3805 Old Easton Road, Doylestown, PA 19403, USA e-mail: shailu@synergypharma.com

Acknowledgments E. P. Shea, PhD (Ironwood Pharmaceuticals) provided writing assistance in the development of this letter to the editor.

\section{Conflict of interest None.}

Open Access This article is distributed under the terms of the Creative Commons Attribution Noncommercial License which permits any noncommercial use, distribution, and reproduction in any medium, provided the original author(s) and the source are credited.

\section{References}

1. Shailubhai K, Comiskey S, Foss JA, et al. Plecanatide, an oral guanylate cyclase $\mathrm{C}$ agonist acting locally in the gastrointestinal tract, is safe and well-tolerated in single doses. Dig Dis Sci. 2013;58:2580-2586

2. Busby RW, Bryant AP, Bartolini WP, et al. Linaclotide, through activation of guanylate cyclase $\mathrm{C}$, acts locally in the gastrointestinal tract to elicit enhanced intestinal secretion and transit. Eur J Pharmacol. 2010;649:328-335.

3. Forte LR Jr. Uroguanylin and guanylin peptides: pharmacology and experimental therapeutics. Pharmacol Ther. 2004;104:137-162.

4. Hamra FK, Krause WJ, Eber SL, et al. Opossum colonic mucosa contains uroguanylin and guanylin peptides. Am J Physiol. 1996;270:G708-G716.

5. Nataro JP, Kaper JB. Diarrheagenic Escherichia coli. Clin Microbiol Rev. 1998;11:142-201.

6. Popoff MR. Multifaceted interactions of bacterial toxins with the gastrointestinal mucosa. Future Microbiol. 2011;6:763-797.

7. Sears CL, Kaper JB. Enteric bacterial toxins: mechanisms of action and linkage to intestinal secretion. Microbiol Rev. 1996;60: 167-215.

8. Busby RW, Kessler MM, Bartolini WP, et al. Pharmacologic properties, metabolism, and disposition of linaclotide, a novel therapeutic Peptide approved for the treatment of irritable bowel syndrome with constipation and chronic idiopathic constipation. $J$ Pharmacol Exp Ther. 2013;344:196-206.

9. Lembo AJ, Schneier HA, Shiff SJ, et al. Two randomized trials of linaclotide for chronic constipation. $N$ Engl J Med. 2011;365: 527-536.

10. Hamra FK, Eber SL, Chin DT, Currie MG, Forte LR. Regulation of intestinal uroguanylin/guanylin receptor-mediated responses by mucosal acidity. Proc Natl Acad Sci. 1997;94:2705-2710. 